\title{
Factors Affecting Individual Taxpayers on the Individual Taxpayers’ Annual Tax Return Reporting with Tax Sanctions as Moderating Variables at Pratama Medan Barat Tax Office
}

\author{
Neni Wahyuni ${ }^{1}$, Idhar Yahya $^{1}$, Sirojuzilam ${ }^{1}$ \\ ${ }^{1}$ Department of Accounting, Faculty of Economics and Business at Universitas Sumatera Utara, Indonesia. \\ Corresponding Author: Neni Wahyuni
}

\begin{abstract}
This study aims to empirically prove the effect of taxation knowledge, tax supervision, tax socialization, taxpayer awareness, and quality of tax services on individual taxpayers' annual tax return reporting with tax sanctions as a moderating variable. Respondents in this study were 100 individual taxpayers registered at Pratama West Medan. The sampling technique in this research is using the purposive sampling technique. The data used are primary. The data analysis tool used is SEM-PLS.

The study results indicate that tax knowledge and tax service quality significantly affect reporting individual taxpayers' annual tax returns at the Pratama Medan Barat Tax Office. Tax sanctions are able to moderate the effect of taxation socialization on the reporting of the annual tax return of individual taxpayers at the Pratama Medan Barat Tax Office. However, it cannot moderate the effect of tax knowledge, tax supervision, taxpayer awareness and quality of tax services on the reporting of individual taxpayers' annual tax returns at the Pratama Medan Barat Tax Office.
\end{abstract}

Keywords: tax knowledge, tax control, tax socialization, tax awareness, tax service quality, tax sanction, individual taxpayers' annual tax return reporting

\section{INTRODUCTION}

The year of 2020 will be the first year of implementing the 2020-2024 National Medium-Term Development Plan
(NMTDP). This plan is the initial momentum for Indonesia to prioritize development that leads to strengthening the foundation of competitiveness before entering the developed country phase in 2036-2045. The national economy's performance that shows uncertainty is a shared record of increasing state revenues to optimize NMTDP optimally.

Based on the latest economic conditions still facing global economic uncertainty, Indonesia's economic growth in 2020 is expected to grow well. For this reason, support is needed to design fiscal policy appropriately, considering that state revenues from the tax sector are the most considerable revenue each year. So that increasing competitiveness to prepare Indonesia to become a developed country can be carried out effectively.

Tax revenue is the primary source of state revenue. Based on the 2020 Financial Note, the contribution of the tax revenue target reached $83.54 \%$ or Rp. $1,865.7$ T. The contribution of tax revenue must continue to be optimized as a source of state revenue and a fiscal instrument amidst the uncertainty of the global economy, which is still weak at this time. The following is the data of registered taxpayers and those who report the annual tax return of individual taxpayers at Pratama Medan Barat Tax Office. 
Neni Wahyuni et.al. Factors affecting individual taxpayers on the individual taxpayers' annual tax return reporting with tax sanctions as moderating variables at Pratama Medan Barat Tax Office.

Table 1. Number of Taxpayers Registered at Pratama Medan Barat Tax Office

\begin{tabular}{|l|l|l|l|}
\hline Years & $\begin{array}{l}\text { Number of Registered } \\
\text { Taxpayers }\end{array}$ & $\begin{array}{l}\text { Number of Taxpayers Reporting } \\
\text { Annual Tax Returns }\end{array}$ & $\begin{array}{l}\text { Number of Taxpayers Do Not } \\
\text { Report Annual Tax Returns }\end{array}$ \\
\hline 2017 & 28.211 & 8.804 & 372 \\
\hline 2018 & 29.185 & 8.984 & 1.459 \\
\hline 2019 & 30.346 & 9.448 & 1.874 \\
\hline 2020 & 34.406 & 9.941 & 1.699 \\
\hline
\end{tabular}

Source: PDI Section, Pratama Medan Barat Tax Office (2021)

The data above shows that noncompliant taxpayers (not reporting SPT) from 2017 - 2020 have increased. In 2019, the number of taxpayers who did not report an annual tax return reached the highest number. The factor that causes the number of individual taxpayers who do not report the annual tax return is the lack of supervision by the DGT (The Directorate General To Taxation). It may occur because the contribution of individual taxpayers in tax revenue is low, so the DGT's focus is only on corporate taxpayers.

Based on Article 1 Paragraph 11 of Law Number 16 of 2009, the annual tax return is a letter taxpayers use to report the calculation and payment of taxes, tax objects, and non-tax objects and assets and liabilities following the provisions of tax laws and regulations. The annual tax return is divided into two types, namely periodic tax return and annual tax return. The annual tax return is a tax report submitted once a year (annually) either by corporate taxpayers or individual taxpayers. It relates to the calculation and payment of income tax, income tax objects and non-income tax objects, and assets and liabilities following the tax regulations for one tax year or part of the tax year. In this research, we will discuss the annual tax return of individual taxpayers.

Restu (2014) states that taxpayer compliance is the attitude or behavior of taxpayers who carry out all their tax obligations and enjoy all of their tax rights following applicable laws and regulations. Compliance can be defined as registering, calculating, paying, and reporting the annual tax return.

Taxpayer compliance can be seen from the number of annual tax return reports. The number of annual tax return reports can indicate the level of tax revenue that has not been maximized. Several factors that cause taxpayers' high level of non-compliance in reporting the annual tax return are the large number of individual taxpayers who do not know their obligations as taxpayers. Knowledge and understanding of taxpayers towards the law and the taxation system are essential factors causing individuals not to report the annual tax return. For this reason, it is hoped that the Directorate General of Taxes will consistently disseminate information to individual taxpayers regarding tax regulations so that individual taxpayers can quickly fulfill their tax obligations.

Taxpayer compliance is a driving factor for increasing state revenue in the taxation sector. The government needs to study intensively the factors that affect taxpayer compliance. It can provide an optimal level of tax revenue. It is expected to benefit taxpayers and all Indonesian people with optimal tax revenue. Several factors that influence taxpayer compliance that will be discussed in this study are tax knowledge, tax supervision, tax socialization, taxpayer awareness, quality of public services, and tax sanctions as moderating variables.

Resmi (2009) states that knowledge and understanding of tax regulations are how taxpayers know about taxation and apply that knowledge to pay taxes. Knowledge and understanding of tax regulations in question understand and understand General Provisions And Taxation Procedures, including submitting an annual tax return, payments, places of payment, fines, and deadlines for payment or reporting an annual tax return. Tax knowledge is tax information that taxpayers can use as a basis for acting, making decisions, and taking specific directions or strategies to implement their rights and 
obligations in the field of taxation (Veronica, 2009).

Knowledge and understanding of taxpayers regarding tax regulations relate to taxpayers' perception of their behavior in compliance with paying taxes. The higher the knowledge and understanding of the taxpayer, the taxpayer can determine his behavior better and follow tax provisions so that taxpayers have a high level of compliance in reporting the Annual Tax Return of Individual Taxpayers. However, suppose the taxpayer does not understand the tax regulations and processes. In that case, the taxpayer cannot determine his behavior correctly, so that the compliance in reporting the taxpayer's annual tax return is low.

Puthur et al. (2015) stated that supervision is the act of determining or evaluating work performance and applying corrective actions so that the work results follow the established plan. Pamuji et al. (2014) said that supervision was carried out to prevent irregularities, fraud, negligence, and weaknesses so that unwanted losses would not occur. Tax supervision is a systematic effort to analyze the performance of taxpayers, plans, or goals that have been previously determined so that it can be seen whether it is in line with the plan or not. Sari et al. (2013) state that tax supervision consists of tax intensification and extensification. Tax intensification maximizes tax revenue with existing tax objects, which does not add to its tax objects. Meanwhile, tax extensification increases tax revenue by adding new tax objects that previously did not exist. Tax supervision can be carried out by applying a Taxpayer Identification Number for each individual and corporate taxpayer; this is done to make it easier for tax officials to supervise taxpayers in fulfilling their tax obligations. Supervision carried out by tax officers will make it easier for them to see the performance in fulfilling tax compliance, such as reporting the annual tax return.
Rohmawati et al. (2012) stated that socialization is an activity or effort carried out by a specific person or organization that informs something (information) to be known by the public or certain circles. Tax socialization is an effort by the DGT, especially the tax service office, to provide understanding, information, and guidance to the public regarding all matters relating to taxation and tax legislation. Tax socialization activities have an essential role in disseminating taxes to all taxpayers. Tax socialization is an effort by the DGT to provide understanding, information, and guidance to the public in general and taxpayers in particular regarding all matters relating to tax laws and regulations. Socialization to individual taxpayers is highly expected to understand taxpayers reporting their annual tax returns. With the socialization of taxation carried out by the DGT, it is hoped that effective participation from the public and taxpayers will be created in fulfilling their rights and obligations to enable the preservation of tax awareness.

The current tax system gives full authority to taxpayers to calculate, pay and report their tax payable or a self-assessment system. Kiryanto (2018) states that with implementing the new taxation system, it is hoped that justice and truth will be created, considering that the taxpayer concerned knows the amount of tax owed. Muliari et al. (2011) stated that tax awareness is a condition in which taxpayers know, understand, and implement tax provisions correctly and voluntarily. Nugroho (2016) said that awareness of paying taxes could be interpreted as a form of moral attitude that contributes to the state to support state development and strives to comply with all regulations that have been set by the state and can be imposed on taxpayers.

The weak awareness of taxpayers can be seen from the low level of reporting of the annual tax return of individual taxpayers. For that, the government needs an active role. In this case, the DGT can provide direction and motivation regarding 
public awareness, incredibly individual taxpayers in compliance with reporting the annual tax return. This report will significantly affect the wheels of state government, especially in terms of state revenues. Tax policy can also create awareness of taxpayers. Policies that do not burden taxpayers can be used as a tool to stimulate or stimulate taxpayers to implement and increase awareness in tax compliance.

Quality is a dynamic condition related to human services, processes, and the environment that meet or exceed the expectations of those who want them (Auliani et al., 2014). Boediono (2018) states that service is a process of helping others in a certain way that requires sensitivity and interpersonal relationships to create satisfaction and success. The quality of good tax services is to provide optimal service by providing space for taxpayers to consult directly with tax officials. If the taxpayer experiences problems in terms of taxation, the taxpayer can immediately consult with the Account Representative (AR).

In fulfilling their obligations to pay taxes, taxpayers depend on how tax officials provide the best quality of service. Fiskus are expected to have competence in the sense of having expertise, knowledge, and experience in tax policy, tax administration, and tax legislation. Tax officers are given the responsibility to serve and supervise several taxpayers who are included in the realm of their work. It will make it easier for tax officers to provide excellent service to taxpayers. Tax officials must always provide maximum service quality to pleasure taxpayers so that taxpayers can quickly fulfill their tax obligations because of the friendly service provided by tax officers.

Mardiasmo (2018) defines tax sanctions as a guarantee that the provisions of tax laws and regulations (tax norms) will have complied. Tax sanctions are also interpreted as a preventive tool so that taxpayers do not violate tax norms. The legal basis for administrative sanctions is regulated in Article 1 of The Law on General Provisions and Tax Procedures. Administrative sanctions can be imposed if the Taxpayer commits a violation, especially on the obligations specified in the law. There are two kinds of tax sanctions in tax law: criminal sanctions and administrative sanctions. Threats to violation of a tax norm are threatened with administrative sanctions, criminal sanctions, and administrative and criminal sanctions, and the difference lies in the consequences. In administrative sanctions, the consequence is the payment of losses to the state in the form of interest and increases, while in criminal sanctions, the consequences are torture or suffering.

In implementing the imposition of sanctions, the DGT has determined the amount of the sanctions tariffs. The provisions on the number of tariffs are regulated in the Taxation Law. It is done, so tax officials do not abuse authority and not set sanctions arbitrarily. The amount of sanctions given by the DGT to individual taxpayers who do not submit their annual tax returns is Rp. 100,000. The higher the severity of the sanctions, the more detrimental the taxpayer will be. The reason for taking sanctions as a moderating variable is because, according to researchers, the more decisive factor influencing taxpayer compliance in fulfilling their obligations as taxpayers is sanctions.

\section{PREVIOUS RESEARCH REVIEW}

Saragih (2013) concludes that the variables of tax socialization, tax service quality, tax sanctions have a positive effect on taxpayer compliance. While partially socialization of taxation does not positively affect taxpayer compliance. Lubis (2015) shows simultaneously the perception of attitudes towards justice from the tax system, social norms, individual norms, perceptions of the probability of noncompliance being found, and the perception of the amount of penalty having a 
Neni Wahyuni et.al. Factors affecting individual taxpayers on the individual taxpayers' annual tax return reporting with tax sanctions as moderating variables at Pratama Medan Barat Tax Office.

significant effect on tax compliance intentions. While partially for tax compliance intentions, social norms, individual norms, perceptions of the probability of non-compliance are found, and perceptions of the size of the penalty have a significant effect on tax compliance intentions. The perception of attitudes towards justice from the tax system has no significant effect on tax compliance intentions.

Sinambela (2013) concluded that simultaneously reform of tax administration (polite actions, special education, independence, facilities, and special service units) affected the level of taxpayer compliance at Pratama Waingapu Tax Office. The influential variables are special education, independence, and special service units that affect taxpayer compliance partially. In contrast, tax counseling is a moderating variable affecting the relationship between tax administration reform (polite actions, special education, independence, facilities, and special service units) on the level of tax compliance at Pratama Waingapu Tax Office.

Santioso \& Kusnawati (2013) concluded that the variables of knowledge about taxes and willingness to pay taxes empirically influence taxpayer compliance. In comparison, the variables of taxpayers' perceptions of tax officers and taxpayers' perceptions of the criteria of compliant taxpayers empirically do not affect taxpayer compliance tax. Kamil (2015) concludes that taxpayer awareness has a positive and significant effect on taxpayer compliance. Knowledge has a negative and significant relationship with taxpayer compliance. Tax sanctions and tax authority services are positively and significantly related to taxpayer compliance.

Based on the explanation above, the researcher is interested in conducting a study titled "Factors Affecting The Annual Tax Returns Reporting of Individual Taxpayers With Tax Sanctions as Moderating Variables at Pratama Medan Barat Tax Office."

\section{Framework}

Following the description of the background of the problem, literature review, and previous research, a conceptual research framework is prepared as follows:

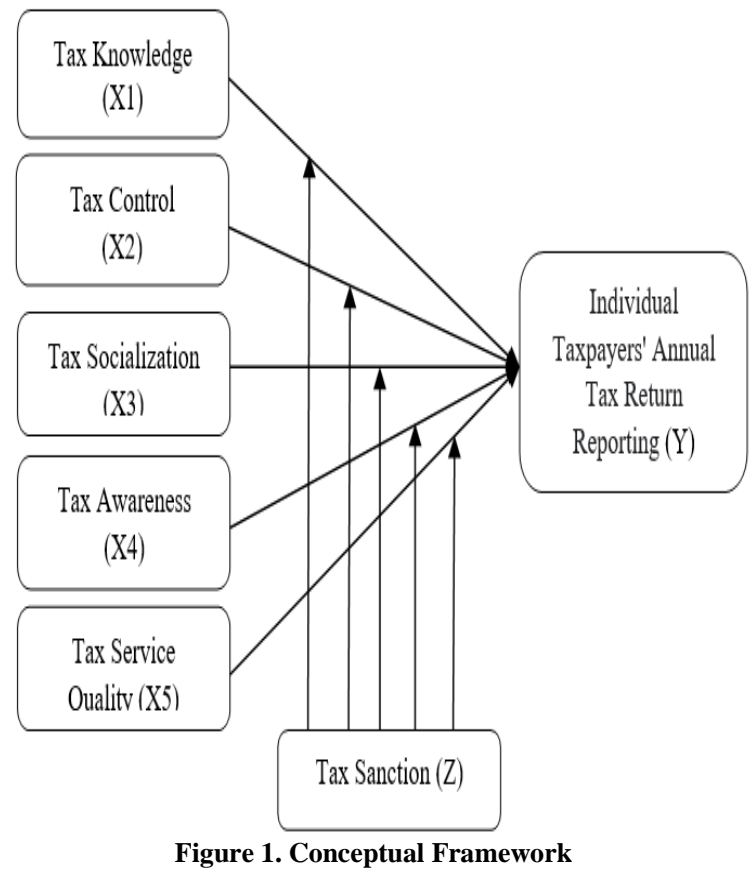

H1: Knowledge of taxation (X1) significantly affects individual taxpayers' annual tax return reporting.

H2: Tax control (X2) positively and significantly affects individual taxpayers' annual tax return reporting.

H3: Tax socialization (X3) positively and significantly affects individual taxpayers' annual tax return reporting.

H4: Taxpayer awareness (X4) has a positive and significant effect on individual taxpayers' annual tax return reporting.

H5: The quality of tax service (X5) has a positive and significant effect on individual taxpayers' annual tax return reporting.

H6: Tax sanctions can moderate the effect of tax knowledge on individual taxpayers' annual tax return reporting.

H7: Tax sanctions can moderate the effect of tax control on individual taxpayers' annual tax return reporting.

H8: Tax sanctions can moderate the effect of tax socialization on individual taxpayers' annual tax return reporting. 
Neni Wahyuni et.al. Factors affecting individual taxpayers on the individual taxpayers' annual tax return reporting with tax sanctions as moderating variables at Pratama Medan Barat Tax Office.

H9: Tax sanctions can moderate the effect of taxpayer awareness on individual taxpayers' annual tax return reporting.

H10: Tax sanctions can moderate the effect of the quality of tax services on individual taxpayers' annual tax return reporting.

\section{RESEARCH METHODS}

This type of research is causal associative research to determine the effect of Tax Knowledge, Tax Supervision, Tax Socialization, Taxpayer Awareness, and Tax Service Quality as independent variables on the Annual Tax Return Reporting of Individual Taxpayers as the dependent variable with Tax Sanctions as the moderating variable. The causal associative study analyzes the relationship between one variable and another to determine how one affects other variables (Erlina, 2011).

The technique in this study used a survey technique, namely a questionnaire. The data analysis method used in this study is a statistical analysis method using Partial Least Square (PLS). Data analysis performs by testing standard assumptions and testing hypotheses.

The population in this study are individual taxpayers who are registered at the Pratama Medan Barat Tax Service Office. The sampling technique used a purposive sampling technique. The sample in this study was 100 correspondents.

\section{RESULT AND DISCUSSION Description of Research Data}

The standard deviation value in table 2. above shows that the overall standard deviation value does not exceed the mean value. It means that the data in this study is categorized as good with the assumption that the standard deviation value is smaller than the mean value. It shows that the mean value can represent accurate data. The descriptive statistical test above also obtained a positive mean value for all variables. Meanwhile, the standard deviation value also shows a smaller than the mean.
Table 2.Descriptive Statistics of Respondents' Answers

\begin{tabular}{|c|c|c|c|c|c|c|}
\hline Variabels & $\mathrm{N}$ & Min & Max & Mean & $\begin{array}{l}\text { Standard } \\
\text { Deviation }\end{array}$ & Category \\
\hline \multicolumn{7}{|l|}{$\begin{array}{c}\text { Tax } \\
\text { Knowledge } \\
\text { (X1) }\end{array}$} \\
\hline TW 1 & 100 & 1 & 5 & 3.910 & 0.736 & Good \\
\hline TK 2 & 100 & 1 & 5 & 3.800 & 0.775 & Good \\
\hline TK 3 & 100 & 1 & 5 & 4.080 & 0.833 & Good \\
\hline TK 4 & 100 & 1 & 5 & 4.080 & 0.833 & Good \\
\hline TK 5 & 100 & 1 & 5 & 4.100 & 0.755 & Good \\
\hline TK 6 & 100 & 1 & 5 & 3.380 & 0.837 & Good \\
\hline \multicolumn{7}{|l|}{$\begin{array}{l}\text { Tax Control } \\
\text { (X2) }\end{array}$} \\
\hline TC 1 & 100 & 1 & 5 & 4.120 & 0.828 & Good \\
\hline TC 2 & 100 & 1 & 5 & 4.240 & 0.850 & Good \\
\hline TC 3 & 100 & 1 & 5 & 4.370 & 0.844 & Good \\
\hline TC 4 & 100 & 1 & 5 & 4.330 & 0.861 & Good \\
\hline TC 5 & 100 & 1 & 5 & 4.240 & 0.826 & Good \\
\hline \multicolumn{7}{|l|}{$\begin{array}{c}\text { Tax } \\
\text { Socialization } \\
\text { (X3) }\end{array}$} \\
\hline TS 1 & 100 & 1 & 5 & 4.350 & 0.899 & Good \\
\hline TS 2 & 100 & 1 & 5 & 4.200 & 0.927 & Good \\
\hline TS 3 & 100 & 1 & 5 & 4.000 & 0.938 & Good \\
\hline TS 4 & 100 & 1 & 5 & 3.910 & 0.907 & Good \\
\hline TS 5 & 100 & 1 & 5 & 4.120 & 0.863 & Good \\
\hline \multicolumn{7}{|l|}{$\begin{array}{c}\text { Taxpayer } \\
\text { Awareness } \\
\text { (X4) }\end{array}$} \\
\hline TA 1 & 100 & 1 & 5 & 3.990 & 0.755 & Good \\
\hline TA 2 & 100 & 1 & 5 & 3.930 & 0.816 & Good \\
\hline TA 3 & 100 & 1 & 5 & 4.300 & 0.819 & Good \\
\hline TA 4 & 100 & 1 & 5 & 4.290 & 0.816 & Good \\
\hline TA 5 & 100 & 1 & 5 & 4.300 & 0.714 & Good \\
\hline TA 6 & 100 & 1 & 5 & 4.040 & 0.824 & Good \\
\hline \multicolumn{7}{|l|}{$\begin{array}{l}\text { Tax Service } \\
\text { Quality (X5) }\end{array}$} \\
\hline TSQ 1 & 100 & 1 & 5 & 4.130 & 0.956 & Good \\
\hline TSQ 2 & 100 & 1 & 5 & 4.070 & 1.003 & Good \\
\hline TSQ 3 & 100 & 1 & 5 & 4.000 & 0.980 & Good \\
\hline TSQ 4 & 100 & 1 & 5 & 4.170 & 0.960 & Good \\
\hline TSQ 5 & 100 & 1 & 5 & 4.050 & 0.973 & Good \\
\hline TSQ 6 & 100 & 1 & 5 & 4.140 & 0.990 & Good \\
\hline TSQ 7 & 100 & 1 & 5 & 4.070 & 1.032 & Good \\
\hline \multicolumn{7}{|l|}{$\begin{array}{l}\text { Tax Sanction } \\
\text { (Z) }\end{array}$} \\
\hline & 100 & 1 & 5 & 3.910 & 1.078 & Good \\
\hline TS 1 & 100 & 1 & 5 & 3.900 & 0.975 & Good \\
\hline TS 2 & 100 & 1 & 5 & 3.720 & 0.928 & Good \\
\hline TS 3 & 100 & 1 & 5 & 3.770 & 0.882 & Good \\
\hline TS 4 & 100 & 1 & 5 & 3.980 & 0.948 & Good \\
\hline TS 5 & 100 & 1 & 5 & 3.900 & 0.995 & Good \\
\hline TS 6 & 100 & 1 & 5 & 3.880 & 0.962 & Good \\
\hline TS 7 & & & & & & \\
\hline
\end{tabular}

Based on the test results, it can be concluded that Tax Knowledge, Tax Supervision, Tax Socialization, Taxpayer Awareness, Tax Service Quality, Tax Sanctions, and Individual Taxpayers' Annual Tax Return Reporting have been able to give positive values to respondents. 
Neni Wahyuni et.al. Factors affecting individual taxpayers on the individual taxpayers' annual tax return reporting with tax sanctions as moderating variables at Pratama Medan Barat Tax Office.

\section{Outer Model Evaluation (Measurement Model): Validity and Reliability Testing}

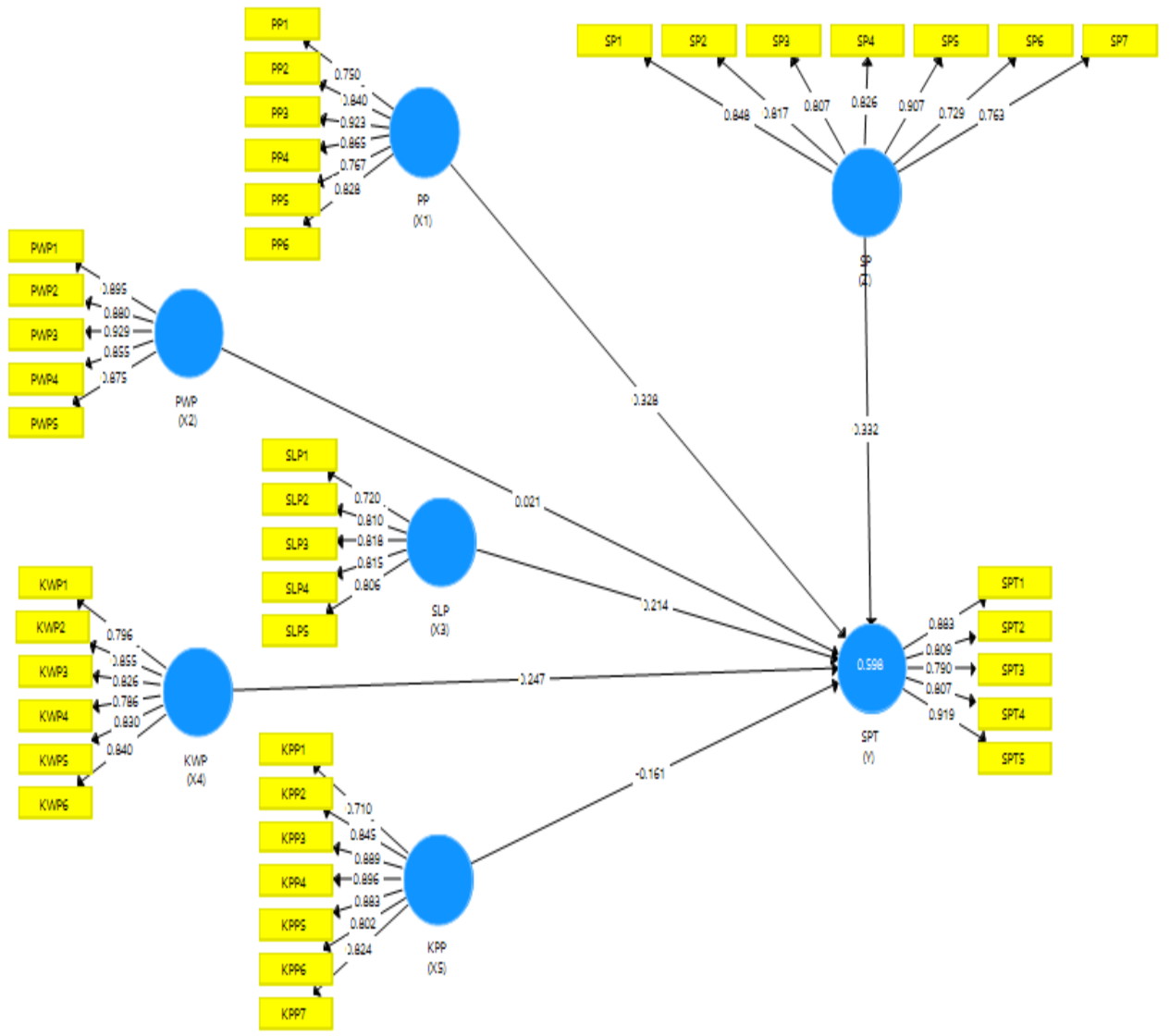

Figure 2. PLS Algorithm Calculation Results Before Moderating Effect

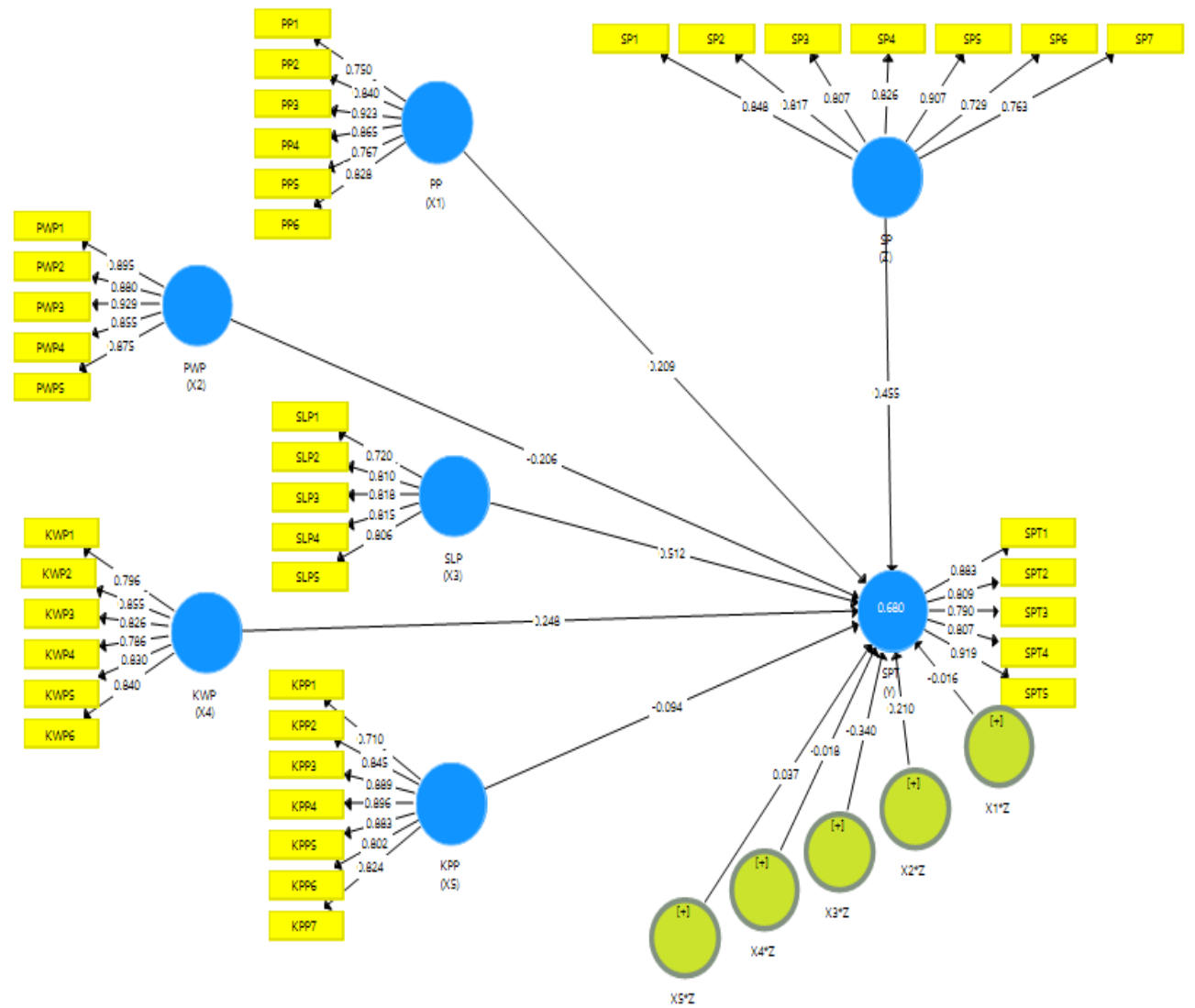

Figure 3. PLS Algorithm Calculation Results After Moderating Effect 
Neni Wahyuni et.al. Factors affecting individual taxpayers on the individual taxpayers' annual tax return reporting with tax sanctions as moderating variables at Pratama Medan Barat Tax Office.

\section{Convergent Validity Test Results Loading Factor}

\begin{tabular}{|c|c|c|c|}
\hline Variables & Indicator & $\begin{array}{l}\text { Loading } \\
\text { Factor }\end{array}$ & Note \\
\hline $\begin{array}{c}\text { Tax } \\
\text { Knowledge } \\
(\mathrm{X} 1)\end{array}$ & $\begin{array}{l}\text { TW } 1 \\
\text { TK } 2 \\
\text { TK } 3 \\
\text { TK } 4 \\
\text { TK } 5 \\
\text { TK } 6\end{array}$ & $\begin{array}{l}0.750 \\
0.840 \\
0.923 \\
0.865 \\
0.767 \\
0.828\end{array}$ & $\begin{array}{l}\text { Valid } \\
\text { Valid } \\
\text { Valid } \\
\text { Valid } \\
\text { Valid } \\
\text { Valid }\end{array}$ \\
\hline $\begin{array}{c}\text { Tax Control } \\
\text { (X2) }\end{array}$ & $\begin{array}{l}\text { TC } 1 \\
\text { TC } 2 \\
\text { TC } 3 \\
\text { TC } 4 \\
\text { TC } 5\end{array}$ & $\begin{array}{l}0.825 \\
0.880 \\
0.929 \\
0.855 \\
0.875\end{array}$ & $\begin{array}{l}\text { Valis } \\
\text { Valid } \\
\text { Valid } \\
\text { Valid } \\
\text { Valid }\end{array}$ \\
\hline $\begin{array}{c}\text { Tax } \\
\text { Socialization } \\
\text { (X3) }\end{array}$ & $\begin{array}{l}\text { TS } 1 \\
\text { TS } 2 \\
\text { TS } 3 \\
\text { TS } 4 \\
\text { TS } 5\end{array}$ & $\begin{array}{l}0.720 \\
0.810 \\
0.818 \\
0.815 \\
0.806 \\
\end{array}$ & $\begin{array}{l}\text { Valid } \\
\text { Valid } \\
\text { Valid } \\
\text { Valid } \\
\text { Valid }\end{array}$ \\
\hline $\begin{array}{c}\text { Taxpayer } \\
\text { Awareness } \\
\text { (X4) }\end{array}$ & $\begin{array}{l}\text { TA } 1 \\
\text { TA } 2 \\
\text { TA } 3 \\
\text { TA } 4 \\
\text { TA } 5 \\
\text { TA } 6\end{array}$ & $\begin{array}{l}0.796 \\
0.855 \\
0.826 \\
0.786 \\
0.830 \\
0.840\end{array}$ & $\begin{array}{l}\text { Valid } \\
\text { Valid } \\
\text { Valid } \\
\text { Valid } \\
\text { Valid } \\
\text { Valid }\end{array}$ \\
\hline $\begin{array}{l}\text { Tax Service } \\
\text { Quality (X5) }\end{array}$ & $\begin{array}{l}\text { TSQ } 1 \\
\text { TSQ } 2 \\
\text { TSQ } 3 \\
\text { TSQ } 4 \\
\text { TSQ } 5 \\
\text { TSQ } 6 \\
\text { TSQ } 7\end{array}$ & $\begin{array}{l}0.710 \\
0.845 \\
0.889 \\
0.896 \\
0.883 \\
0.802 \\
0.824 \\
\end{array}$ & $\begin{array}{l}\text { Valid } \\
\text { Valid } \\
\text { Valid } \\
\text { Valid } \\
\text { Valid } \\
\text { Valid } \\
\text { Valid }\end{array}$ \\
\hline $\begin{array}{l}\text { Annual Tax } \\
\text { Return } \\
\text { Reporting } \\
\text { for } \\
\text { Individual } \\
\text { Taxpayers } \\
\text { atPratama } \\
\text { Medan } \\
\text { Barat Tax } \\
\text { Office (Y) }\end{array}$ & $\begin{array}{l}\text { ATRR } 1 \\
\text { ATRR } 2 \\
\text { ATRR } 3 \\
\text { ATRR } 4 \\
\text { ATRR } 5\end{array}$ & $\begin{array}{l}0.883 \\
0.809 \\
0.790 \\
0.807 \\
0.919\end{array}$ & $\begin{array}{l}\text { Valid } \\
\text { Valid } \\
\text { Valid } \\
\text { Valid } \\
\text { Valid }\end{array}$ \\
\hline $\begin{array}{c}\text { Tax } \\
\text { Sanction (Z) }\end{array}$ & $\begin{array}{l}\text { TS } 1 \\
\text { TS } 2 \\
\text { TS } 3 \\
\text { TS } 4 \\
\text { TS } 5 \\
\text { TS } 6 \\
\text { TS } 7\end{array}$ & $\begin{array}{l}0.848 \\
0.817 \\
0.807 \\
0.826 \\
0.907 \\
0.729 \\
0.763 \\
\end{array}$ & $\begin{array}{l}\text { Valid } \\
\text { Valid } \\
\text { Valid } \\
\text { Valid } \\
\text { Valid } \\
\text { Valid } \\
\text { Valid }\end{array}$ \\
\hline
\end{tabular}

Source: Calculation Results of SmartPLS 3.0

The test results through Smart-PLS obtained the loading factor value of all variables that meet the criteria, namely $>$ 0.7 . Value $>0.7$ indicates that all loading factor values in the table are valid or have met the rule of thumb. The loading factor value $>0.7$ means that all variables are suitable for use in research. The loading factor value $>0.7$ means that the indicator can explain the variable by $70 \%$.

\section{AVE (Average Variance Extracted)}

\begin{tabular}{|l|l|l|}
\hline Tariables & AVE VALUE & NOTE \\
\hline X1 & 0.690 & Valid \\
\hline X2 & 0.787 & Valid \\
\hline X3 & 0.632 & Valid \\
\hline X4 & 0.676 & Valid \\
\hline X5 & 0.702 & Valid \\
\hline Z & 0.665 & Valid \\
\hline $\mathrm{Y}$ & 0.711 & Valid \\
\hline
\end{tabular}

Based on the PLS Algorithm test results in table 4, all variables have an AVE value $>0.05$. So it can be concluded that each construct has met convergent validity. The AVE result of each variable $>0.5$ indicates a good correlation between the indicators and each construct, which means that more than $50 \%$ of the variance of the indicators can be explained.

\section{Discriminant Validity Test Results}

Table 5. Value of Square Root AVE Fornell Larcker Criterion

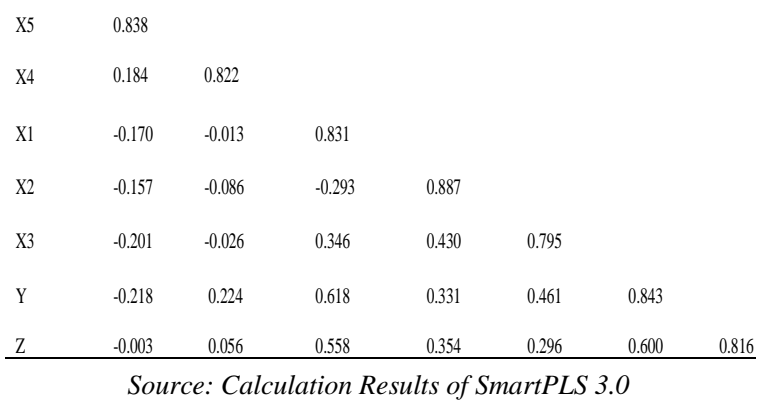

Based on table 5. it can be seen that the value of the square root of the AVE Fornell Larcker Criterion for each construct is higher than the correlation value. As an example, the AVE root value of the tax knowledge construct is 0.831 , which is higher than the correlation value between taxation knowledge and tax control, which is -0.293 . Then it can be concluded that the model has met the research criteria (valid) because it has met the discriminant validity.

\section{Reliability Test Results}

\begin{tabular}{|l|l|l|l|}
\hline \multicolumn{5}{|c|}{ Table 6. Reliability Test Results } \\
\hline Variables & $\begin{array}{l}\text { Composite } \\
\text { Reliability }\end{array}$ & $\begin{array}{l}\text { Cronbach's } \\
\text { Alpa }\end{array}$ & Note \\
\hline X1 & 0.930 & 0.911 & Reliable \\
\hline X2 & 0.949 & 0.935 & Reliable \\
\hline X3 & 0.895 & 0.866 & Reliable \\
\hline X4 & 0.926 & 0.905 & Reliable \\
\hline X5 & 0.943 & 0.936 & Reliable \\
\hline Y & 0.925 & 0.898 & Reliable \\
\hline Z & 0.933 & 0.918 & Reliable \\
\hline
\end{tabular}

Based on table 6. the composite reliability and Cronbach's alpha values for each construct are $>0.7$. Based on the research criteria that set the limit of the reliable value for the reliability test is 0.7 , it can be concluded that the indicators used in this study have met good reliability (reliable). 
Neni Wahyuni et.al. Factors affecting individual taxpayers on the individual taxpayers' annual tax return reporting with tax sanctions as moderating variables at Pratama Medan Barat Tax Office.

\section{Testing Data Analysis Requirements (Inner Model Evaluation) R-Square (R2) Analysis}

Table 7. R-Square (R2) Analysis Result

\begin{tabular}{|l|l|l|}
\hline Variable (Construct) Endogen & $\begin{array}{l}\boldsymbol{R} \text { Square } \\
\text { Adjusted }\end{array}$ & Note \\
\hline $\begin{array}{l}\text { Annual Tax Return Reporting for } \\
\text { Individual Taxpayers at Pratama Medan }\end{array}$ & 0,640 & Strong \\
Barat Tax Office & & \\
\hline
\end{tabular}

Source: Calculation Results of SmartPLS 3.0

Based on the data processing results with the PLS Algorithm, the R-Square Adjusted value is 0.640 . It means the influence of the variable knowledge of taxation (X1), tax control (X2), tax socialization (X3), taxpayer awareness (X4), and tax service quality (X5) in generating or influencing the reporting of annual tax returns of individual taxpayers at Pratama Medan Barat Tax Office by 64\%. The remaining $36 \%$ is influenced by other factors outside of this research model.

\section{Result Effect Size (f $\left.{ }^{2}\right)$}

The formula calculates the calculation of effect size for moderation:

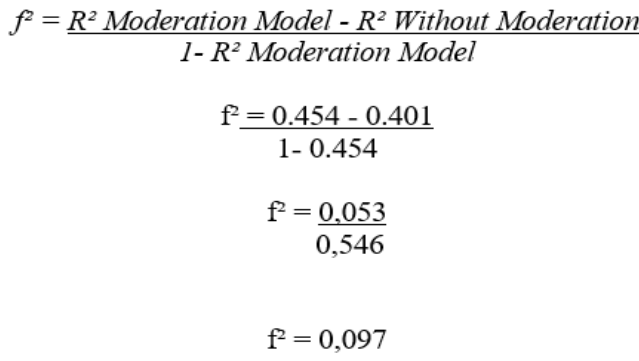

Based on the calculation results, the effect size value is 0.097 . These results show that the tax sanctions variable as a moderating variable has a weak influence on the influence between exogenous variables and endogenous variables.

\section{Direct Influence Test}

Table 8. Direct Influence Test Result

\begin{tabular}{|l|l|l|l|l|}
\hline Construct & Path Coefficient & T Statistic & P Values & Note \\
\hline $\mathrm{X} 5 \rightarrow \mathrm{Y}$ & 0.161 & 1.999 & 0.046 & Significant \\
\hline $\mathrm{X} 4 \rightarrow \mathrm{Y}$ & 0.247 & 1.467 & 0.143 & Not Significant \\
\hline $\mathrm{X} 1 \rightarrow \mathrm{Y}$ & 0.328 & 2.047 & 0.041 & Significant \\
\hline $\mathrm{X} 2 \rightarrow \mathrm{Y}$ & 0.021 & 0.226 & 0.822 & Not Significant \\
\hline $\mathrm{X} 3 \rightarrow \mathrm{Y}$ & 0.214 & 1.892 & 0.059 & Not Significant \\
\hline \multicolumn{4}{|c|}{ Source: Calculation Results of SmartPLS 3.0 } \\
\hline
\end{tabular}

Source: Calculation Results of SmartPLS 3.0

Based on the table above, it can be concluded that the direct effect of the X5 variable on $\mathrm{Y}$ is 0.161 , meaning that if $\mathrm{X} 5$ increases by one unit, $\mathrm{Y}$ can increase by $16.1 \%$, which is positive and applies to the $\mathrm{X} 4-\mathrm{X} 1$ variable.

\section{Moderation Effect Test}

Table 9. Moderation Effect Test
\begin{tabular}{|l|l|l|l|l|}
\hline Construct & Path Coefficient & T Statistic & P Values & Note \\
\hline $\mathrm{X} 5 \rightarrow \mathrm{Y}$ & 0.161 & 1.999 & 0.046 & Significant \\
\hline $\mathrm{X} 4 \rightarrow \mathrm{Y}$ & 0.247 & 1.467 & 0.143 & Not Significant \\
\hline Moderating Effect 1 $\rightarrow \mathrm{Y}$ & $-0,016$ & 0,126 & 0,900 & Not Significant \\
\hline Moderating Effect 2 $\rightarrow \mathrm{Y}$ & 0,210 & 1,660 & 0,097 & Not Significant \\
\hline Moderating Effect 3 $\rightarrow \mathrm{Y}$ & $-0,340$ & 1,986 & 0,050 & Significant \\
\hline Moderating Effect 4 $\rightarrow \mathrm{Y}$ & $-0,018$ & 0,183 & 0,855 & Not Significant \\
\hline Moderating Effect 5 $\rightarrow \mathrm{Y}$ & 0.037 & 0,511 & 0,610 & Not Significant \\
\hline $\mathrm{X} 1 \rightarrow \mathrm{Y}$ & 0.328 & 2.047 & 0.041 & Significant \\
\hline $\mathrm{X} 2 \rightarrow \mathrm{Y}$ & 0.021 & 0.226 & 0.822 & Not Significant \\
\hline $\mathrm{X} 3 \rightarrow \mathrm{Y}$ & 0.214 & 1.892 & 0.059 & Not Significant \\
\hline $\mathrm{Z} \rightarrow \mathrm{Y}$ & 0,455 & 3,181 & 0,002 & Significant \\
\hline \multicolumn{2}{|l|}{ Source: Calculation Results of SmartPLS 3.0} & \\
\hline
\end{tabular}

The effect of the moderating effect can be seen from the effect size $\left(\mathrm{f}^{2}\right)$ values, namely 0.02 (weak), 0.15 (moderate), and 0.35 (strong). Based on the study results of only 0.097 , it can be concluded that the moderating effect in this study is categorized as weak. 
Neni Wahyuni et.al. Factors affecting individual taxpayers on the individual taxpayers' annual tax return reporting with tax sanctions as moderating variables at Pratama Medan Barat Tax Office.

\section{Hypothesis Test Results}

Based on table 9, the results of hypothesis testing can be described as follows:

1. Based on the results of the H1 test, it produces a positive path coefficient of 0.328 and a t-statistic value of 2.047, and the P-Value is $0.041<0.05$. Then $\mathrm{H1}$ is accepted.

2. Based on the test results, $\mathrm{H} 2$ produces a negative path coefficient of 0.021 , a tstatistic value of 0.226 , and the P-Value is $0.822>0.05$. Then $\mathbf{H} 2$ is rejected.

3. Based on the results of the H3 test, it produces a positive path coefficient of 0.214 and a t-statistic value of 1.892, and the P-Value is $0.059>0.05$. Then $\mathrm{H} 3$ is rejected.

4. Based on the results of the $\mathrm{H} 4$ test, it produces a positive path coefficient of 0.247 and a t-statistic value of 1.467 , and the P-Value is $0.143>0.05$. Then $\mathrm{H} 4$ is rejected.

5. Based on the results of the $\mathrm{H} 5$ test, it produces a negative path coefficient of 0.161 and a t-statistic value of 1.999, and the P-Value is $0.046<0.05$. Then $\mathrm{H} 5$ is accepted.

6. Based on the test results, H6 produces a path coefficient of -0.016 , a t-statistic value of 0.126 , and the $\mathrm{P}-\mathrm{Value}$ is 0.900 $>0.05$. Then $\mathrm{H6}$ is rejected.

7. Based on the test results, $\mathrm{H} 7$ produces a path coefficient value of 0.210 , a $t-$ statistic value of 1.660 , and the P-Value is $0.097>0.05$. Then $\mathbf{H 7}$ is rejected.

8. Based on the H8 test, the path coefficient value is -0.340 , the t-statistic value is 1.99 , and the P-value is $0.050=$ 0.05. Then $\mathbf{H 8}$ is accepted.

9. Based on the H9 test, the path coefficient value is -0.018 , the $t$-statistic value is 0.183 , and the $P$-value is $0.855>0.05$. Then $\mathbf{H 9}$ is rejected.

10. Based on the H10 test, the path coefficient value is 0.037 , the t-statistic value is 0.511 , and the P-Value is 0.610 $>0.05$. Then $\mathbf{H 1 0}$ is rejected.

\section{CONCLUSION}

Based on the results of data analysis and research discussion, the following conclusions can be drawn:

1. Knowledge of taxation has a positive and significant effect on individual taxpayers' annual tax return reporting at Pratama Medan Barat Tax Office.

2. Tax control has no significant effect on individual taxpayers' annual tax return reporting at Pratama Medan Barat Tax Office.

3. Socialization of taxation has no significant effect on individual taxpayers' annual tax return reporting at Pratama Medan Barat Tax Office.

4. Taxpayer awareness does not significantly affect the individual taxpayers' annual tax return reporting at Pratama Medan Barat Tax Office.

5. The quality of tax services has a positive and significant effect on individual taxpayers' annual tax return reporting at Pratama Medan Barat Tax Office.

6. Tax sanctions cannot moderate (strengthen) the effect of tax knowledge on individual taxpayers' annual tax return reporting at Pratama Medan Barat Tax Office.

7. Tax sanctions cannot moderate (strengthen) the effect of tax control on individual taxpayers' annual tax return reporting at Pratama Medan Barat Tax Office.

8. Tax sanctions can provide a moderating effect (strengthen) the effect of tax socialization on individual taxpayers' annual tax return reporting at Pratama Medan Barat Tax Office.

9. Tax sanctions cannot moderate (strengthening) the effect of taxpayer awareness on individual taxpayers' annual tax return reporting at Pratama Medan Barat Tax Office.

10. Tax sanctions cannot provide a moderating effect (strengthen) the effect of the quality of tax services on individual taxpayers' annual tax return reporting at Pratama Medan Barat Tax Office. 


\section{Limitations Of The Research}

1. This research was conducted during the Covid-19 pandemic, so that researchers were limited to conducting research and obtaining more complete data.

2. Many of the respondents were reluctant to fill out the questionnaire because they protected themselves from being exposed to Covid-19. Furthermore, the researcher also did not have contact respondents. The distribution of the questionnaires could only be done manually, so it took a long time to collect the questionnaires.

3. This research was only conducted at Pratama Medan Barat Tax Office with limited time and human resources. So that the results of the study only discuss and produce the conditions for the annual tax return reporting of individual taxpayers at the Pratama Medan Barat Tax Office.

4. The variables in this study are limited to certain variables. Other variables related to individual taxpayers' annual tax return reporting can still be developed so that the research results are comprehensive.

5. This study only uses individual taxpayers registered at Pratama Medan Barat Tax Office. It cannot conclude that all the annual tax return reporting of individual taxpayers' compliance is in North Sumatra (generalized).

\section{SUGGESTION}

1. This research was only conducted at the Pratama Pratama Medan Barat Tax Office with a small and limited number of samples. It is hoped that further research can be developed for all Pratama Tax Office in the North Sumatra 1 area to get more transparent and more representative research results.

2. For further research, researchers should be more responsive by approaching and explaining the importance of research and filling out questionnaires based on knowledge and what is felt by respondents so that research results are based on actual conditions.
3. This study only examines five exogenous variables, namely tax knowledge, tax supervision, tax socialization, taxpayer awareness, and tax service quality, and one moderating variable, namely tax sanctions endogenous variables.

4. In addition to distributing questionnaires, further researchers can also conduct interviews with respondents to obtain additional information, add research samples so that research results are comprehensive.

5. Tax socialization is the dominant variable in increasing the annual SPT reporting of individual taxpayers at KPP Pratama Medan Barat. So it is hoped that the DGT can continuously improve the tax socialization program and supervision.

\section{Acknowledgement: None}

Conflict of Interest: None

\section{Source of Funding: None}

\section{REFERENCES}

1. Auliani, S. N., Kamio, K., \& Supadi, S. (2014). Analisis Penetapan NJOP terhadap Harga Pasar dengan Metode Assessment Sales Ratio dalam Kaitannya dengan Potensi Pajak Bumi (Studi Kasus Tanah di Kecamatan Serpong Utara, Kota Tangerang Selatan). Eko-Regional: Jurnal Pembangunan Ekonomi Wilayah, 7(2).

2. Boediono, G. T., Sitawati, R., \& Harjanto, S. (2018). Analisis pengaruh sosialisasi perpajakan terhadap kepatuhan wajib pajak dengan kesadaran sebagai variabel mediasi. Jurnal Penelitan Ekonomi dan Bisnis, 3(1), 22-38.

3. Erlina. 2011. Metodologi Penelitian. Sumatera Utara: USU Press.

4. Kamil, I. (2015). Pengaruh Kesadaran Wajib Pajak, Pengetahuan, Denda Pajak, dan Layanan Otoritas Pajak Tentang Kepatuhan Pajak : (Survei Wajib Pajak Orang Pribadi di Jabodetabek dan Bandung).. Jurnal Online Insan Akuntan, 2(2), 259-270. 
Neni Wahyuni et.al. Factors affecting individual taxpayers on the individual taxpayers' annual tax return reporting with tax sanctions as moderating variables at Pratama Medan Barat Tax Office.

5. Kiryanto, K., \& Lestari, I. A. (2018). Dampak International Financial Reporting Standard (IFRS) terhadap Penghindaran Pajak (Tax Avoidance). Jurnal RAK (Riset Akuntansi Keuangan), 3(2), 143-161.

6. Lubis, M. I. (2015). Analisis Faktor-Faktor yang Mempengaruhi Kepatuhan Wajib Pajak Orang Pribadi di Kantor Pelayanan Pajak Pratama Medan Polonia.

7. Mardiasmo Kalangi, L., \& Pontoh, W. (2018). Pengaruh Pemeriksaan Pajak Dan Sanksi Perpajakan Terhadap Kepatuhan Wajib Pajak Pada Kantor Pelayanan Pajak Pratama Manado. Going Concern: Jurnal Riset Akuntansi, 13(04).

8. Muliari, N. K., \& Setiawan, P. E. (2011). Pengaruh persepsi tentang sanksi perpajakan dan Kesadaran wajib pajak pada kepatuhan Pelaporan wajib pajak orang pribadi di kantor Pelayanan pajak pratama denpasar timur. Jurnal Ilmiah Akuntansi dan Bisnis, 6(1).

9. Nugroho, A., Andini, R., \& Raharjo, K. (2016). Pengaruh kesadaran wajib pajak dan pengetahuan perpajakan wajib pajak terhadap kepatuhan wajib pajak dalam membayar pajak penghasilan (studi kasus pada KPP Semarang Candi). Journal of Accounting, 2(2).

10. Pamuji, W., \& Abdillah, W. (2014). Pendapatan Asli Daerah, Dana Bagi Hasil Pajak dan Bukan Pajak, Dana Alokasi Umum dan Dana Alokasi Khusus dan Belanja Modal pada Kabupaten/Kota Provinsi Jawa Barat. Jurnal Riset Akuntansi \& Perpajakan (JRAP), 1(02), 149-159.

11. Puthur, J. K., Mahadevan, L., \& George, A. P. (2015). Taxpayer Satisfaction and Intention to Re-use Government site for Efiling. Editorial Team Editorial Advisory Board, 46.

12. Republik Indonesia. 2009. Undang-Undang Nomor 16 Tahun 2009 Tentang Ketentuan Umum dan Tata Cara Perpajakan.

13. Resmi, Siti. 2011. Perpajakan Teori dan Kasus. Jakarta Selatan: Salemba Empat.

14. Restu, Y. (2014). Analisis Kinerja Pajak Daerah Di Kabupaten Tanah Datar (Doctoral dissertation, Universitas Andalas).
15. Rohmawati, A. N., \& Rasmini, N. K. (2012). Pengaruh Kesadaran, Penyuluhan, Pelayanan, Dan Sanksi Perpajakan Pada Kepatuhan Wajib Pajak Orang Pribadi. EJurnal Akuntansi Universitas Udayana, 1(2), 1-17.

16. Sahata, Sinambela. "Pengaruh Reformasi Administrasi Perpajakan terhadap Tingkat Kepatuhan Wajib Pajak di KPP Pratama Waingapu (Penyuluhan Pajak Sebagai Variabel Moderating)." (2013). (CHICAGO)

17. Santioso, L., \& Kusnawati, K. (2013). Analisis Pengaruh Pengetahuan Pajak, Persepsi Wajib Pajak dan Kemauan Membayar Pajak Terhadap Kepatuhan Wajib Pajak di KPP Pratama Jakarta Kebon Jeruk Dua Tahun 2011.Karya Ilmiah Dosen, 6(12), 114-214.

18. Saragih, S. F. (2013). Analisis Pengaruh Sosialisasi Perpajakan, Kualitas Pealayanan Fiskus, dan Pelaksanaan Sanksi Perpajakan terhadap Kepatuhan Wajib Pajak Orang Pribadi Dikantor Pelayanan Pajak (KPP) Pratama Medan Timur.

19. Sari, N., Djuanda, G., \& Sarwani, S. (2017). Pengaruh Dana Perimbangan, Dana Sisa Lebih Perhitungan Anggaran (SiLPA) Dan Pendapatan Asli Daerah (PAD) Terhadap Belanja Modal Dan Dampaknya Pada Pertumbuhan Ekonomi Di Wilayah Bodetabek Periode 2006 s/d 2015. Proceedings Universitas Pamulang, 2(1).

20. Veronica, A. (2009). Pengaruh Sosialisasi Perpajakan, Pelayanan Fiskus, Pengetahuan Pajak, Persepsi Pengetahuan Korupsi, Dan Sanksi Perpajakan Terhadap Kepatuhan Wajib Pajak Orang Pribadi (WPOP) Pada KPP Pratama Senapelan Pekanbaru. Jom. FEKON, 2(2), 1-15.

How to cite this article: Neni Wahyuni, Idhar Yahya, Sirojuzilam. Factors affecting individual taxpayers on the individual taxpayers' annual tax return reporting with tax sanctions as moderating variables at Pratama Medan Barat Tax Office. International Journal of Research and Review. 2021; 8(12): 557-568. DOI: https://doi.org/10.52403/ijrr.20211268 